\title{
Comparison of Real Estate Values Determined in Poland and Ukraine in Context of State Border Historical Changes ${ }^{* * * *}$
}

\begin{abstract}
As an outcome of the state border changes determined by the warfare in Europe during the first half of the $20^{\text {th }}$ century, some of the migrating population were forced to leave their properties located in what had suddenly become a different country.

The country of Poland compensated its citizens for real property losses resulting from leaving such properties outside of the new country borders. The Polish legislation then came out with new procedures that enabled such a property valuation. These are based on the Real Estate Management Act. The valuation is conducted based on similar real property appraisal; properties that are located in comparable market areas within the current borders of Poland. The purpose of the study is to verify whether the determined value corresponds with the current market value within a local real estate market. As an example, we used a sample property located in Lviv. Value estimation was exercised twice - based on data available for the local market (Lviv) and for the market determined according to the comparability to Polish regulations; i.e., on the basis of real estate data in Krakow.
\end{abstract}

Keywords: right to compensation, property valuation, comparable market

* AGH University of Science and Technology, Faculty of Mining Surveying and Environmental Engineering, Department of Geomatics, Krakow, Poland

** Lviv National Agrarian University, Department of Land Cadastre, Lviv, Ukraine

*** Lviv National Agrarian University, Department of Geodesy and Geoinformatics, Lviv, Ukraine

**** This work is financed from funds science realized at AGH University of Science and Technology, allocated for the year 2018 


\section{Introduction}

The problem with properties left by Polish citizens in territories located to the east side of the Curzon Line arose as a consequence of the wartime activities in Europe during the first half of the $20^{\text {th }}$ century and as a result of the political consequences of such activities. After World War II ended, Europe's stability and its political map underwent significant changes. Changes in the borders led to a mass migration of Polish citizens, who eventually settled within the "new" Polish state. It is estimated that the problem touched about 2 million people who left the Eastern Borderlands. The most-significant waves of population migration occurred during the years 1944-1952, when the rules for the repatriation of Polish citizens were established based on the republican agreements [12, 13]. As a consequence of the above-mentioned migration, the Polish state obligated itself to solve the problem of the property left by citizens outside the current borders of Poland. For this reason, citizens entitled to lost property compensation are subject only to Polish law and should refer to it when investigating their claims.

Up until the adoption of the Compensation Act [2] in 2005 (the Act on Exercising the Right to Compensation for Property Left Outside the Current Borders of the Polish State), execution of compensation for lost property for the benefit of persons entitled and the subjective scope of persons who could apply for the compensation due came to change [14]. The Compensation Act in its current wording is also a result of many amendments to the original form of the 2005 act.

In accordance with the Compensation Act, the left-behind property compensation procedure requires the submission of an appraisal report for the property in question (among other things). The Polish law has developed procedures to enable the valuation of such types of real estate. They are based on the Real Estate Management Act [1]. Valuation is conducted based on similar properties located within the areas of comparable markets within the current borders of Poland.

The main objective of this study is to compare the market value determined in accordance to the rules of right to compensation for real estate left outside the current borders of Poland with the market value of such property in the local real estate market.

\section{Real Estate Appraisal Guidelines for Properties Left Outside of Present Borders of Poland}

Among the fundamental legal acts regulating appraisal issues of properties left outside the current Polish borders, we can list the following:

- Act of July 8, 2005 on Exercising the Right to Compensation for Property Left Outside the Current Borders of the Polish State (Journal of Laws of 2005, item 1418 with amendments), 
- Act of August 21, 1997 on Real Estate Management (Journal of Laws of 1997, item 741 with amendments),

- Regulation of the Council of Ministers of September 21, 2004 on Real Estate Valuation and Preparation of Appraisal Report (Journal of Laws of 2004, item 2109 with amendments).

To assume an appraisal report for an abandoned property is correct, it is required to prepare such a report based on documentary evidence in accordance with the Compensation Act. The market value of such real estate is estimated based on a comparable market within the present Polish borders and identical with the real estate market where the property was located according to the Compensation Act.

To assume the given real estate market is similar, such a market shall meet the following requirements:

- a similar number of people,

- a similar degree of urbanization,

- a similar administrative character.

Such a market shall operate in a voivodship or city corresponding to the administrative unit where the abandoned property was located. According to the Compensation Act, equivalents for particular real estate markets together with the factors to be included in the final phase of valuation are presented in Table 1.

Table 1. Similar markets for abandoned properties with coefficients

\begin{tabular}{||l|l|c||}
\hline \multicolumn{1}{|c|}{ Market for abandoned property } & \multicolumn{1}{|c|}{$\begin{array}{c}\text { Similar market located within current } \\
\text { borders of Poland }\end{array}$} & Coefficient \\
\hline \hline \multirow{2}{*}{ Lwowskie Voivodship } & Podkarpackie Voivodship & 0.00 \\
\hline \multirow{2}{*}{ Stanisławowskie Voivodship } & Małopolskie Voivodship & 0.76 \\
\cline { 2 - 3 } & Podkarpackie Voivodship & 0.74 \\
\hline \multirow{2}{*}{ Wołyńskie Voivodship } & Małopolskie Voivodship & 0.84 \\
\cline { 2 - 3 } & Podkarpackie Voivodship & 0.84 \\
\hline Poleskie Voivodship & Lubelskie Voivodship & 1.02 \\
\cline { 2 - 3 } & Świętokrzyskie Voivodship & 0.71 \\
\hline \multirow{2}{*}{ Wileńskie Voivodship } & Podlaskie Voivodship & 0.64 \\
\hline \multirow{2}{*}{ Nowogródzkie Voivodship } & Podlaskie Voivodship & 0.41 \\
\cline { 2 - 3 } & Mazowieckie Voivodship & 0.80 \\
\hline Białostockie Voivodship & Podlaskie Voivodship & 0.52 \\
\cline { 2 - 3 } & Mazowieckie Voivodship & 1.00 \\
\hline city of Lviv & Podlaskie Voivodship & 1.00 \\
\hline \hline
\end{tabular}

Source: Act on Exercising the Right to Compensation for Property Left Outside the Current Borders of the Polish State 
The abandoned property value is estimated based on the average transaction prices taken from a similar market, with respect to the methodology in accordance with the Real Estate Management Act and Regulation of Property Valuation and Preparation of Appraisal Report. When a comparative approach is used, it is expected that both real estate price volatility over time and similarity of properties due to their characteristics are taken into account $[4,9,15]$. It is strongly advised to take into account the legal status, land-use planning purposes, manner of using the property, as well as its physical features [6, 8]. In the case of properies left outside of Polish borders, the reliability of the documentary evidence is crucial. The issue of assessing the quality of documentation and possibility of using it in the estimated market value when exercising a comparative approach is also strongly emphasized when assessing similar properties accepted for valuation [16].

In case transaction prices are not available, the cost approach should be used to estimate the value of buildings or their parts. In such a case, the replacement value of the property is determined. For this purpose, the broadest-possible references to data from the local real estate market should be used [5, 7].

It is important to keep in mind that the determined value of real property left outside the current Polish borders should be determined as of the date of its abandonance by the repatriate and (in the case of cost-approach validation) according to its status as of the date of such appraisal.

\section{Property Valuation Principles in Sales Comparative Approach in Ukraine}

Fundamental legal statutes that apply to real estate considered in further part of work valuation are as follows:

- Act of Ukraine of July 12, 2001 on property valuation, property rights, and professional activities related to the valuation [3],

- Resolution of the Council of Ministers of Ukraine of September 10, 2003, Number 1440 on national standard No. 1 approval "General principles of property valuation and property rights" [17],

- Resolution of the Council of Ministers of Ukraine of October 28, 2004, Number 1442 on national standard No. 2 approval "Property valuation" [18],

- Resolution of the Council of Ministers of Ukraine of December 10, 2003, Number 1891 on methodology of "Property valuation approval" [19].

In the real estate-valuation practice in Ukraine, the following methodical approaches are used:

- comparative approach (sales analogs),

- investment approach,

- cost approach. 
Within the comparative approach, it is assumed that that transaction data for analogue objects to the valued real estate are known, and the value is determined as a result of the characteristics of the real estate sold to the property valued comparison. Such an approach is based on the substitution rule, saying that a buyer will not pay a higher price for a property than for another property with the same characteristics.

The model of market value calculation in the comparison approach is as follows:

$$
C_{o}=C_{a} \cdot w_{r}
$$

where:

$C_{o}$ - value of the appraised property,

$C_{a}$ - value of the analog object,

$w_{r}$ - difference coefficient between the test object and analog object.

After selecting the comparative unit, the key indicators and elements of the comparison are identified. Such data is used to enter the necessary adjustments to the sale prices of similar objects.

There are a number of comparison elements:

- the object of research ownership rights $\left(w_{p w}\right)$ - property restrictions objectively reduces the value of the test object;

- purchase of a given asset financial records $\left(w_{r f}\right)$ - various options within financial settlements (e.g., day of sale settlement, deferred payment);

- terms of sale $\left(w_{w s}\right)$ - e.g., free sale or forced sale; elimination of some analogues from comparison or adjustment to sale prices by identifying deviations from market conditions of sales;

- dynamics of the market transactions $\left(w_{d r}\right)$ - impact of the time factor resulting from inflation, deflation, changes in supply and demand for real estate, etc.;

- location $\left(w_{1}\right)$ - among others, the attractiveness resulting from the location in various functional and economic zones related to spatial planning, etc.;

- physical properties $\left(w_{w f}\right)$ - assessing the suitability of the test object; the following factors are taken into account: age and technical condition of the object, type of building materials, real estate area, architecture and construction, decorations, etc.

The factor that determines the difference between the test object and analog object can be calculated using the formula below:

$$
w_{r}=w_{p w} \cdot w_{r f} \cdot w_{w s} \cdot w_{d r} \cdot w_{l} \cdot w_{w f}
$$

The above approach is used when information about the sale of items with characteristics similar to the subject of the research is available.

The described valuation method is the most reliable, because both the primary and secondary real estate markets are presently shaped and there is sufficient information about the analogous objects. 


\section{Valuation of Research Object}

The subject of the valuation is a land property built up as a tenement house as a subject of ownership. The tenement house was built at the end of the $19^{\text {th }}$ century and, according to archival documentation, is located at Nowy Świat 4 in Lviv, Ukraine. It is in the central part of the city, surrounded by the following streets: Książe Andrzej Potocki (now called Generała Czuprynki), Sapieha (nowadays Stefan Bandery), Śniadeckich (now Politechniczna), and Głęboka. The building is located on lot No. 4827 with an area of $413.61 \mathrm{~m}^{2}$. The tenement house is a three-story building with a non-residential attic and consists of a main part and an outbuilding. It has a completed basement and its own backyard. Two separate entrances with staircases lead to the tenement house, and there are 9 to 11 rooms on each floor. The valued tenement house has been preserved in very good condition up until present day. The calculated area of the tenement house estimated on the basis of the measurements given in a technical plan is $503.55 \mathrm{~m}^{2}$. The location of the valued real estate on a modern plan as well as a map from 1939 is presented in Figure 1.

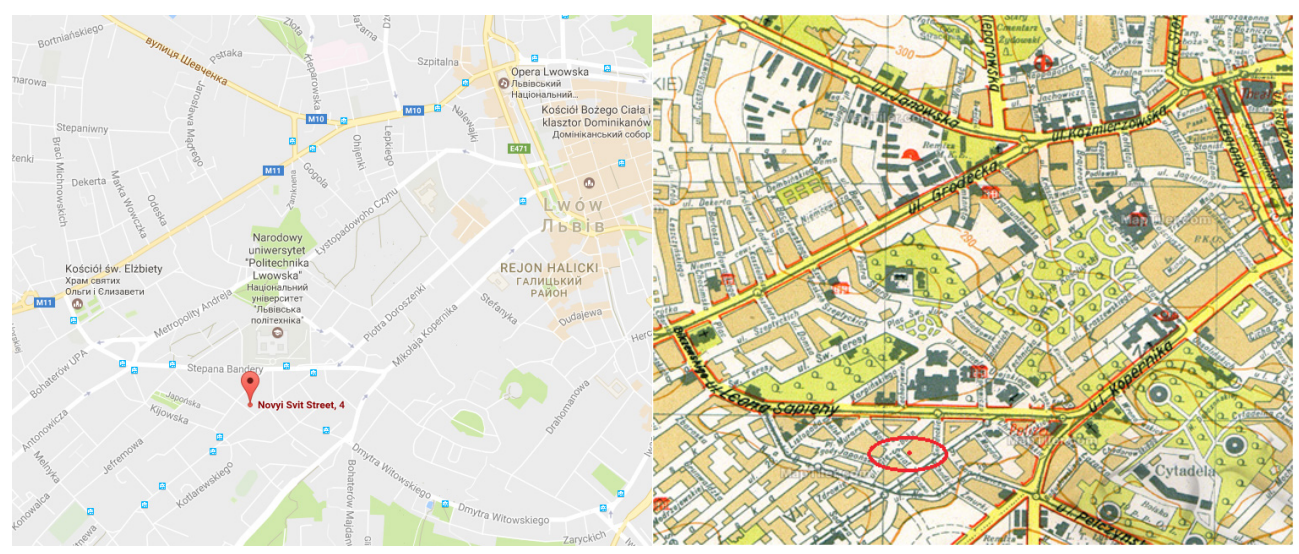

Fig. 1. Location of valued real estate on modern plan and map from 1939

Source: $[10,11]$

In the first option, the valuation was made according to the Compensation Act. According to the indicated act, the equivalent to the city of Lviv is currently the city of Krakow. Therefore, transaction data from the local real estate market of Krakow were accepted for the valuation. Just like Lviv, Krakow is an urban center with a considerable advantage of pre-war and historic tenement houses located in its central part. For the purpose of market analysis and valuation, a database of nine properties located in the Śródmieście district was formulated. These properties were traded during the years of 2013-2016. The appraisal was made as for December 7, 
2016. Due to the price stabilization observed during the analyzed period, the correction of prices on the valuation date was omitted.

Table 2 presents the real estate base for market analysis and property valuation.

Table 2. Real estate base with characteristics - data from city of Krakow

\begin{tabular}{|c|c|c|c|c|c|c|c|c|}
\hline \multirow[b]{2}{*}{ No. } & \multirow[b]{2}{*}{ Address } & \multicolumn{5}{|c|}{ Value of attribute } & \multirow{2}{*}{$\begin{array}{c}\text { Usable } \\
\text { floor area } \\
{\left[\mathrm{m}^{2}\right]}\end{array}$} & \multirow{2}{*}{$\begin{array}{l}\text { Unit price } \\
{\left[\mathrm{PLN} / \mathrm{m}^{2}\right]}\end{array}$} \\
\hline & & Location & $\begin{array}{l}\text { Surround- } \\
\text { ings }\end{array}$ & $\begin{array}{l}\text { Technical } \\
\text { condition }\end{array}$ & $\begin{array}{l}\text { Utili- } \\
\text { ties }\end{array}$ & $\begin{array}{c}\text { Land } \\
\text { area }\end{array}$ & & \\
\hline 1 & Dietla Street & 1 & 1 & 1 & 1 & 1 & $1,114.9$ & 2,960 \\
\hline 2 & Czapskich Street & 2 & 2 & 2 & 1 & 2 & 1,629 & 3,376 \\
\hline 3 & św. Łazarza Street & 1 & 0 & 1 & 2 & 1 & 500 & 4,270 \\
\hline 4 & Batorego Street & 2 & 1 & 1 & 1 & 1 & 1,158 & 3,554 \\
\hline 5 & Rzeszowska Street & 1 & 0 & 0 & 1 & 0 & 592 & 2,804 \\
\hline 6 & Topolowa Street & 2 & 2 & 1 & 2 & 2 & 972.6 & 4,577 \\
\hline 7 & Krupnicza Street & 2 & 1 & 1 & 1 & 2 & 1,140 & 3,947 \\
\hline 8 & Sarego Street & 2 & 2 & 2 & 1 & 2 & $1,270.45$ & 5,038 \\
\hline 9 & Tenczyńska Street & 2 & 2 & 0 & 2 & 0 & 938 & 4,264 \\
\hline
\end{tabular}

In addition, the locations of similar properties are marked in Figure 2.

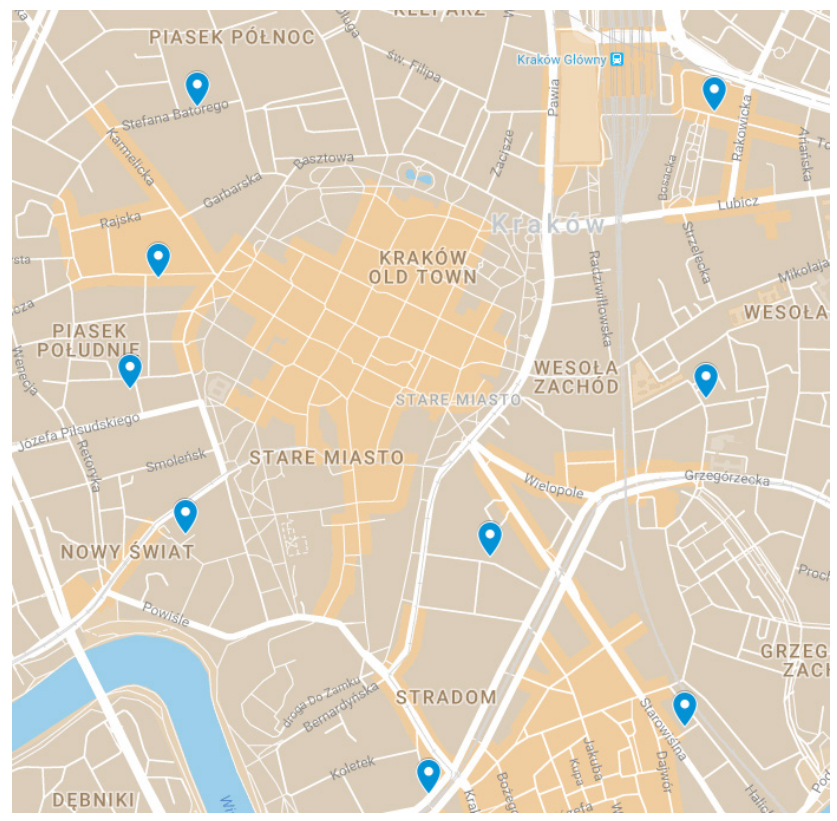

Fig. 2. Location of similar properties to subject of valuation Source: own study based on [10] 
As a result of a correlation of the variable analysis, the weight shares of individual market characteristics were determined (Tab. 3).

Table 3. Weight shares of market characteristics

\begin{tabular}{|c|c|c|c|c|c|c|c|}
\hline & \multirow{2}{*}{\multicolumn{6}{|c|}{ Attribute }} & \multirow{4}{*}{$\Sigma$} \\
\hline & & & & & & & \\
\hline & Location & $\begin{array}{l}\text { Surround- } \\
\text { ings }\end{array}$ & $\begin{array}{l}\text { Technical } \\
\text { condition } \\
\end{array}$ & Utilities & $\begin{array}{l}\text { Land } \\
\text { area }\end{array}$ & $\begin{array}{c}\text { Usable } \\
\text { floor area }\end{array}$ & \\
\hline $\begin{array}{l}\text { Linear correlation } \\
\text { coefficient }\end{array}$ & 0.521 & 0.490 & 0.317 & 0.505 & 0.428 & -0.039 & \\
\hline $\begin{array}{l}\text { Square of linear } \\
\text { correlation coefficient }\end{array}$ & 0.27 & 0.24 & 0.10 & 0.26 & 0.18 & - & 1.05 \\
\hline $\begin{array}{l}\text { Weight shares of market } \\
\text { characteristics [\%] }\end{array}$ & 26 & 23 & 10 & 24 & 17 & - & 100 \\
\hline
\end{tabular}

The market value of the research object was determined as a result of comparisons to the four-most-similar properties from the base for valuation (Tab. 4).

Table 4. Calculation of market value - data from city of Krakow

\begin{tabular}{|c|c|c|c|c|c|c|c|c|c|}
\hline \multirow[b]{2}{*}{ 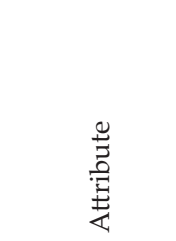 } & \multirow{2}{*}{ 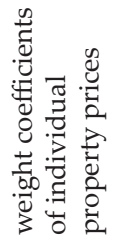 } & \multicolumn{2}{|c|}{ No. 3} & \multicolumn{2}{|c|}{ No. 6} & \multicolumn{2}{|c|}{ No. 7} & \multicolumn{2}{|c|}{ No. 9} \\
\hline & & $\begin{array}{l}\text { Attr. } \\
\text { diff. }\end{array}$ & Correct. & $\begin{array}{l}\text { Attr. } \\
\text { diff. }\end{array}$ & Correct. & $\begin{array}{l}\text { Attr. } \\
\text { diff. }\end{array}$ & Correct. & $\begin{array}{l}\text { Attr. } \\
\text { diff. }\end{array}$ & Correct. \\
\hline Location & 577.28 & 1 & 577.28 & 0 & 0.00 & 0 & 0 & 0 & 0.00 \\
\hline Surroundings & 255.40 & 2 & 510.80 & 0 & 0.00 & 1 & 255.40 & 0 & 0.00 \\
\hline $\begin{array}{l}\text { Technical } \\
\text { condition }\end{array}$ & 106.98 & 1 & 106.98 & 1 & 106.98 & 1 & 106.98 & 2 & 213.96 \\
\hline Utilities & 542.28 & 0 & 0.00 & 0 & 0.00 & 1 & 542.28 & 0 & 0.00 \\
\hline Land area & 194.60 & -1 & -194.60 & -2 & -389.20 & -2 & -389.20 & 0 & 0.00 \\
\hline \multicolumn{2}{|c|}{$\Sigma$} & \multicolumn{2}{|c|}{$\begin{array}{l}1,000.46 \\
\text { PLN/m² }\end{array}$} & \multicolumn{2}{|c|}{$\begin{array}{l}-282.22 \\
\mathrm{PLN} / \mathrm{m}^{2}\end{array}$} & \multicolumn{2}{|c|}{$\begin{array}{c}515.46 \\
\mathrm{PLN} / \mathrm{m}^{2}\end{array}$} & \multicolumn{2}{|c|}{$\begin{array}{c}213.96 \\
\text { PLN/m² }\end{array}$} \\
\hline \multicolumn{2}{|c|}{ Unit price after correction } & \multicolumn{2}{|c|}{$\begin{array}{l}5,270.46 \\
\text { PLN/m² }\end{array}$} & \multicolumn{2}{|c|}{$\begin{array}{l}4,294.69 \\
\text { PLN/m² }\end{array}$} & \multicolumn{2}{|c|}{$\begin{array}{l}4,462.83 \\
\text { PLN/m² }\end{array}$} & \multicolumn{2}{|c|}{$\begin{array}{l}4,478.35 \\
\text { PLN/m² }\end{array}$} \\
\hline
\end{tabular}

As a result of the calculations, the market value of the estimated property was as follows:

$$
503.55 \mathrm{~m}^{2} \cdot 4,626.58 \mathrm{PLN} / \mathrm{m}^{2}=2,329,714 \text { PLN. }
$$


In the second appraisal option, the valuation was based on data taken from the local real estate market of the city of Lviv. Table 5 presents the analog objects adopted for comparisons in the comparative approach to property valuation.

Table 5. Real estate base for comparisons - data from city of Lviv

\begin{tabular}{|c|c|c|c|c|c|c|}
\hline Object number & No. 1 & No. 2 & No. 3 & No. 4 & No. 5 & No. 6 \\
\hline Location & $\begin{array}{l}\text { Naliwajki } \\
\text { Street }\end{array}$ & $\begin{array}{c}\text { Hebrejska } \\
\text { Street }\end{array}$ & $\begin{array}{l}\text { I. Franki } \\
\text { Street }\end{array}$ & $\begin{array}{c}\text { br. } \\
\text { Rogatyńców } \\
\text { Street }\end{array}$ & $\begin{array}{c}\text { Dragoma- } \\
\text { nowa Street }\end{array}$ & $\begin{array}{l}\text { F. Liszta } \\
\text { Street }\end{array}$ \\
\hline Property type & Tenement & Tenement & Tenement & Tenement & Tenement & Tenement \\
\hline $\begin{array}{l}\text { Financial } \\
\text { settlements }\end{array}$ & Normal & Normal & Normal & Normal & Normal & Normal \\
\hline Terms of sale & Free sale & Free sale & Free sale & Free sale & Free sale & Free sale \\
\hline Terms of exposure & $\begin{array}{l}\text { Offered for } \\
\text { sale }\end{array}$ & $\begin{array}{l}\text { Offered for } \\
\text { sale }\end{array}$ & $\begin{array}{l}\text { Offered for } \\
\text { sale }\end{array}$ & $\begin{array}{l}\text { Offered for } \\
\text { sale }\end{array}$ & $\begin{array}{l}\text { Offered for } \\
\text { sale }\end{array}$ & $\begin{array}{c}\text { Offered for } \\
\text { sale }\end{array}$ \\
\hline Land area $\left[\mathrm{m}^{2}\right]$ & 250 & 200 & 600 & 200 & 1,000 & 200 \\
\hline Construction date & $\begin{array}{c}\text { First years } \\
\text { of } 20^{\text {th }} \\
\text { century }\end{array}$ & $\begin{array}{c}\text { First years } \\
\text { of } 20^{\text {th }} \\
\text { century }\end{array}$ & $\begin{array}{c}\text { First years } \\
\text { of } 20^{\text {th }} \\
\text { century }\end{array}$ & $\begin{array}{l}\text { First years } \\
\text { of } 20^{\text {th }} \\
\text { century }\end{array}$ & $\begin{array}{l}\text { First years } \\
\text { of } 20^{\text {th }} \\
\text { century }\end{array}$ & $\begin{array}{c}\text { First years } \\
\text { of } 20^{\text {th }} \\
\text { century }\end{array}$ \\
\hline $\begin{array}{l}\text { Usable floor area } \\
{\left[\mathrm{m}^{2}\right]}\end{array}$ & 1,029 & 300 & 500 & 290 & 1,350 & 1,200 \\
\hline Number of floors & $\begin{array}{l}4+\text { attic + } \\
\text { basement }\end{array}$ & $\begin{array}{c}3+ \\
\text { basement }\end{array}$ & $\begin{array}{c}3+ \\
\text { basement }\end{array}$ & $\begin{array}{c}3+ \\
\text { basement }\end{array}$ & $\begin{array}{c}3+ \\
\text { basement }\end{array}$ & $\begin{array}{c}4+ \\
\text { basement }\end{array}$ \\
\hline $\begin{array}{l}\text { Construction } \\
\text { material }\end{array}$ & Brick & Brick & Brick & Brick & Brick & Brick \\
\hline $\begin{array}{l}\text { Technical } \\
\text { condition }\end{array}$ & Good & Good & Average & Good & Good & Good \\
\hline Gas installation & $\begin{array}{c}\text { Gas } \\
\text { network }\end{array}$ & $\begin{array}{c}\text { Gas } \\
\text { network }\end{array}$ & $\begin{array}{c}\text { Gas } \\
\text { network }\end{array}$ & $\begin{array}{c}\text { Gas } \\
\text { network }\end{array}$ & $\begin{array}{c}\text { Gas } \\
\text { network }\end{array}$ & $\begin{array}{c}\text { Gas } \\
\text { network }\end{array}$ \\
\hline $\begin{array}{l}\text { Electrical } \\
\text { installation }\end{array}$ & $\begin{array}{c}\text { Power } \\
\text { network }\end{array}$ & $\begin{array}{c}\text { Power } \\
\text { network }\end{array}$ & $\begin{array}{c}\text { Power } \\
\text { network }\end{array}$ & $\begin{array}{c}\text { Power } \\
\text { network }\end{array}$ & $\begin{array}{c}\text { Power } \\
\text { network }\end{array}$ & $\begin{array}{c}\text { Power } \\
\text { network }\end{array}$ \\
\hline $\begin{array}{l}\text { Water } \\
\text { installation }\end{array}$ & $\begin{array}{c}\text { Water } \\
\text { network }\end{array}$ & $\begin{array}{c}\text { Water } \\
\text { network }\end{array}$ & $\begin{array}{c}\text { Water } \\
\text { network }\end{array}$ & $\begin{array}{c}\text { Water } \\
\text { network }\end{array}$ & $\begin{array}{c}\text { Water } \\
\text { network }\end{array}$ & $\begin{array}{c}\text { Water } \\
\text { network }\end{array}$ \\
\hline Sewage installation & $\begin{array}{l}\text { Sewage } \\
\text { network }\end{array}$ & $\begin{array}{l}\text { Sewage } \\
\text { network }\end{array}$ & $\begin{array}{l}\text { Sewage } \\
\text { network }\end{array}$ & $\begin{array}{l}\text { Sewage } \\
\text { network }\end{array}$ & $\begin{array}{l}\text { Sewage } \\
\text { network }\end{array}$ & $\begin{array}{l}\text { Sewage } \\
\text { network }\end{array}$ \\
\hline Heating installation & $\begin{array}{l}\text { Autono- } \\
\text { mous }\end{array}$ & $\begin{array}{l}\text { Autono- } \\
\text { mous }\end{array}$ & $\begin{array}{l}\text { Autono- } \\
\text { mous }\end{array}$ & $\begin{array}{l}\text { Autono- } \\
\text { mous }\end{array}$ & $\begin{array}{l}\text { Autono- } \\
\text { mous }\end{array}$ & $\begin{array}{l}\text { Autono- } \\
\text { mous }\end{array}$ \\
\hline Outbuildings & No & No & No & No & No & No \\
\hline $\begin{array}{l}\text { Additional } \\
\text { information }\end{array}$ & No & No & No & No & No & No \\
\hline Offer price [USD] & $1,450,000$ & 510,000 & 680,000 & 575,700 & $1,850,000$ & $1,500,000$ \\
\hline
\end{tabular}


In addition, the locations of similar properties are marked in Figure 3.

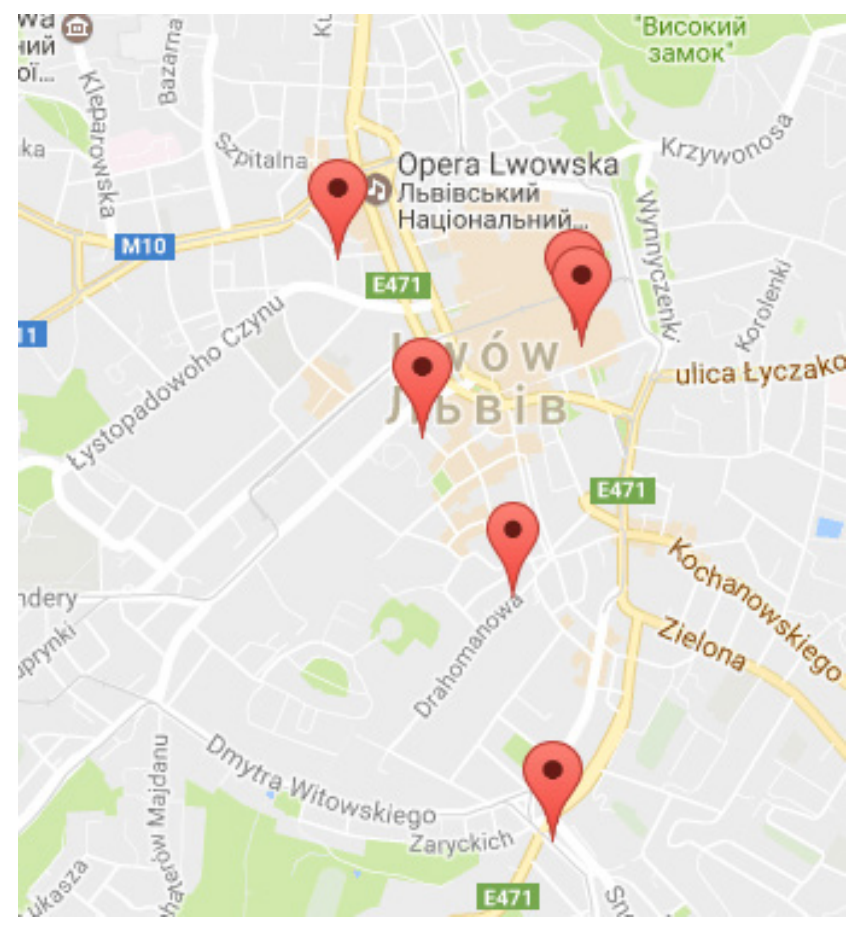

Fig. 3. Location of similar properties to subject of valuation

Source: own study based on [10]

Table 6 presents the individual adjustments for real estate valued in comparison to similar properties.

Table 6. Calculation of the market value - data from city of Lviv

\begin{tabular}{||l|c|c|c|c|c|c|c||}
\hline \multirow{2}{*}{ Parameter } & \multirow{2}{*}{$\begin{array}{c}\text { Valued } \\
\text { property }\end{array}$} & \multicolumn{7}{c||}{ Comparable property } \\
\cline { 3 - 8 } & & No. 1 & No. 2 & No. 3 & No. 4 & No. 5 & No. 6 \\
\hline \hline Offer price [USD] & 503.55 & 1,029 & 300 & 500 & 290 & 1,350 & 1,200 \\
\hline Usable floor area $\left[\mathrm{m}^{2}\right]$ & 413.61 & 250 & 200 & 600 & 200 & 1000 & 200 \\
\hline Land area $\left[\mathrm{m}^{2}\right]$ & - & 1,409 & 1,700 & 1,360 & 1,985 & 1,370 & 1,250 \\
\hline Unit offer price [USD/m²] & - & 1.00 & 1.00 & 1.00 & 1.00 & 1.00 & 1.00 \\
\hline Property right - correction factor & - & 1.00 & 1.00 & 1.00 & 1.00 & 1.00 & 1.00 \\
\hline $\begin{array}{l}\text { Financial settlements - correction } \\
\text { factor }\end{array}$ & - & 1.00 & 1.00 & 1.00 & 1.00 & 1.00 & 1.00 \\
\hline Terms of sale - correction factor & - & & & & & \\
\hline
\end{tabular}


Table 6. cont.

\begin{tabular}{|c|c|c|c|c|c|c|c|}
\hline Location - correction factor & - & 0.895 & 0.861 & 0.958 & 0.861 & 1.000 & 0.895 \\
\hline Property type - correction factor & - & 1.00 & 1.00 & 1.00 & 1.00 & 1.00 & 1.00 \\
\hline $\begin{array}{l}\text { Construction date - correction } \\
\text { factor }\end{array}$ & - & 1.00 & 1.00 & 1.00 & 1.00 & 1.00 & 1.00 \\
\hline $\begin{array}{l}\text { Number of floors - correction } \\
\text { factor }\end{array}$ & - & 1.00 & 1.00 & 1.00 & 1.00 & 1.00 & 1.00 \\
\hline $\begin{array}{l}\text { Usable floor area - correction } \\
\text { factor }\end{array}$ & - & 1.05 & 0.97 & 1.00 & 0.97 & 1.07 & 1.06 \\
\hline $\begin{array}{l}\text { Technical condition - correction } \\
\text { factor }\end{array}$ & - & 0.80 & 0.80 & 1.00 & 0.80 & 0.80 & 0.80 \\
\hline $\begin{array}{l}\text { Gas installation - correction } \\
\text { factor }\end{array}$ & - & 1.00 & 1.00 & 1.00 & 1.00 & 1.00 & 1.00 \\
\hline $\begin{array}{l}\text { Electrical installation - } \\
\text { correction factor }\end{array}$ & - & 1.00 & 1.00 & 1.00 & 1.00 & 1.00 & 1.00 \\
\hline $\begin{array}{l}\text { Water installation - correction } \\
\text { factor }\end{array}$ & - & 1.00 & 1.00 & 1.00 & 1.00 & 1.00 & 1.00 \\
\hline $\begin{array}{l}\text { Sewage installation - correction } \\
\text { factor }\end{array}$ & - & 1.00 & 1.00 & 1.00 & 1.00 & 1.00 & 1.00 \\
\hline $\begin{array}{l}\text { Heating installation - correction } \\
\text { factor }\end{array}$ & - & 1.00 & 1.00 & 1.00 & 1.00 & 1.00 & 1.00 \\
\hline $\begin{array}{l}\text { Built-in furniture, household } \\
\text { appliances, etc. - correction } \\
\text { factor }\end{array}$ & - & 1.00 & 1.00 & 1.00 & 1.00 & 1.00 & 1.00 \\
\hline Outbuildings - correction factor & - & 1.00 & 1.00 & 1.00 & 1.00 & 1.00 & 1.00 \\
\hline $\begin{array}{l}\text { Additional advantages - } \\
\text { correction factor }\end{array}$ & - & 1.00 & 1.00 & 1.00 & 1.00 & 1.00 & 1.00 \\
\hline Total correction factor & - & 0.6388 & 0.5678 & 0.8141 & 0.5678 & 0.7276 & 0.6449 \\
\hline $\begin{array}{l}\text { Unit price after correction } \\
{\left[\mathrm{USD} / \mathrm{m}^{2}\right]}\end{array}$ & - & 900 & 965 & 1,107 & 1,127 & 997 & 806 \\
\hline $\begin{array}{l}\text { Average value of adjusted unit } \\
\text { prices }\end{array}$ & \multicolumn{7}{|c|}{984} \\
\hline Median of adjusted unit prices & \multicolumn{7}{|c|}{981} \\
\hline $\begin{array}{l}\text { Average absolute deviation of } \\
\text { adjusted unit prices }\end{array}$ & \multicolumn{7}{|c|}{93} \\
\hline $\begin{array}{l}\text { Minimum unit value after taking } \\
\text { into account average deviation }\end{array}$ & \multicolumn{7}{|c|}{891} \\
\hline $\begin{array}{l}\text { Maximum unit value after } \\
\text { taking into account average } \\
\text { deviation }\end{array}$ & \multicolumn{7}{|c|}{1,077} \\
\hline $\begin{array}{l}\text { Unit market value of estimated } \\
\text { property }\left[\mathrm{USD} / \mathrm{m}^{2}\right]\end{array}$ & \multicolumn{7}{|c|}{981} \\
\hline $\begin{array}{l}\text { Market value of estimated property } \\
\text { [USD] }\end{array}$ & \multicolumn{7}{|c|}{493,983} \\
\hline
\end{tabular}




\section{Summary}

The market value of real estate left outside of the current borders of Poland is estimated for the purposes of compensation based on data from comparable markets located within the current borders of Poland. At the same time, coefficients are used to determine differences in the level of economic development of voivodships or cities from the first half of the $20^{\text {th }}$ century. Calculations for two variants were to be used to compare the value determined in accordance with the Compensation Act to the current value set on the local real estate market of the city of Lviv. The results of the estimation are presented in Table 7 (after conversion of the zloty to dollar exchange rate as of the date of determining the value of the property).

Table 7. The comparison of market values

\begin{tabular}{|l|c|c|}
\cline { 2 - 3 } \multicolumn{1}{c|}{} & $\begin{array}{c}\text { Unit market value } \\
{\left[\text { [USD } / \mathrm{m}^{2}\right]}\end{array}$ & $\begin{array}{c}\text { Market value } \\
{[\text { [USD] }}\end{array}$ \\
\hline \hline $\begin{array}{l}\text { Data from local real estate market - } \\
\text { city of Lviv }\end{array}$ & 981.00 & 493,983 \\
\hline $\begin{array}{l}\text { Data from local real estate market - } \\
\text { city of Krakow }\end{array}$ & $1,121.11$ & 564,533 \\
\hline
\end{tabular}

Analyzing the market value of real estate determined on the basis of data from a market comparable to the value on the local market, it can be concluded that the obtained results differ within a dozen or so percentage points. The higher value obtained from the data of the equivalent real estate market of the city of Krakow is, among other things, the result of a greater degree of development of this market compared to the city of Lviv. The degree of development of this market is also reflected in the availability of market data for valuation. Access to the sale data of real estate of the local market of Lviv is limited; therefore, estimation is often based on offer data. Lviv real estate price data (in particular tenements) is usually given in US dollars; therefore, a direct value comparison is also conditioned by the volatility of exchange rates.

\section{References}

[1] Act of August 21, 1997 on real estate management. Journal of Laws of 1997, No. 115, item 1774 with amendments [Ustawa $z$ dnia 21 sierpnia 1997 r. o gospodarce nieruchomościami. Dz.U. 1997, nr 115, poz. 741 wraz z późn. zm.].

[2] Act of July 8, 2005 on the use of the right to compensation for property left outside the present borders of the Republic of Poland. Journal of Laws of 2005, No. 169, item 141 with amendments [Ustawa $z$ dnia 8 lipca 2005 r. o realizacji prawa do rekompensaty z tytułu pozostawienia nieruchomości poza obecnymi granicami Rzeczypospolitej Polskiej. Dz.U. nr 169, poz. 1418 wraz z późn. zm.]. 
[3] Act of Ukraine of July 12, 2001 on property valuation, property rights and professional activities related to the valuation [Закон України ві 12 липня 2001 року № 2658-III «Про оцінку майна, майнових прав та професійну оціночну діяльність в Украӥні»].

[4] Adamczyk T.: Application of Huber and Hampel m-estimation in analysing of real estate price volatility over time. [in:] Adamczyk T., Dębińska E. (eds.), "GIS ODYSSEY 2017": Geographic Information Systems Conference and Exhibition: 4th to 8th of September 2017, Trento - Vattaro, Italy: conference proceedings. Croatian Information Technology Society - GIS Forum, Zagreb, pp. 7-12 [electronic document].

[5] Adamczyk T.: Rynkowy współczynnik regionalny w podejściu kosztowym wyceny nieruchomości [The market-based regional indicator in the cost approach to valuation]. Infrastruktura i Ekologia Terenów Wiejskich, nr I/2, 2017, pp. 385-393.

[6] Adamczyk T., Bieda A.: Intended use of real estate as a time changeable attribute for determining compensation for nationalized and expropriated lands. Real Estate Management and Valuation, vol. 22, no. 4, 2014, pp. 35-50.

[7] Adamczyk T., Ruchel J.: Analysis of comparative approach and cost approach in the aspect of real property market value. Geomatics and Environmental Engineering, vol. 9, no. 4, 2015, pp. 15-24.

[8] Bieda A.: Parametric model of real estate valuation for land located in different land-use zones. Geomatics and Environmental Engineering, vol. 11, no. 4, 2017, pp. 17-33.

[9] Bieda A.: Wycena nieruchomości w aspekcie standardów międzynarodowych. [in:] Materiały Krakowskiej Konferencji Młodych Uczonych 2008: Kraków, 25-27 września 2008, Akademia Górniczo-Hutnicza im. Stanisława Staszica w Krakowie, Kraków 2008, pp. 387-393.

[10] Google Maps, https://www.google.pl/maps [access: 15.12.2017].

[11] Lviv map from 1939, http://stareplanymiast.pl/PM/LWOW/PK1939/ [access: 15.12.2017].

[12] Łaski P.: Refleksje na temat żąań odszkodowawczych zabużan z tytułu utraty mienia na Kresach Wschodnich w świetle prawa międzynarodowego i prawa polskiego. Ruch Prawniczy, Ekonomiczny i Socjologiczny, z. 2, 2002, pp. 41-50.

[13] Michniewicz-Wanik K.: Mienie zabużańskie. Prawne podstawy realizacji roszczeń. Wydawnictwo "Nortom", Wrocław 2008.

[14] Młynarska-Sobaczewska A.: Odpowiedzialność państwa polskiego za mienie zabużańskie. Państwo i Prawo, nr 2, 2010, pp. 57-69.

[15] Parzych P., Czaja J.: Szacowanie rynkowej wartości nieruchomości. Wydawnictwa AGH, Kraków 2015.

[16] Rącka I.: Jakość informacji na rynku nieruchomości w Polsce. Problemy Jakości, r. 49, nr 4, 2017, pp. 19-25. 
[17] Resolution of the Council of Ministers of Ukraine of September 10, 2003, Number 1440 on national standard No. 1 approval "General principles of property valuation and property rights" [Постанова Кабінету Міністрів Украйни від 10 вересня 2003 року № 1440 Про затвердження Національного стандарту № 1 «Загальні засади оцзіки майна і майнових прав»].

[18] Resolution of the Council of Ministers of Ukraine of October 28, 2004, Number 1442 on national standard No. 2 approval "Property valuation" [Постанова Кабінету Міністрів Украйни від 28 жовтня 2004 року № 1442 Про затвердження Національного стандарту № 2 «Оиінка нерухомого майна»].

[19] Resolution of the Council of Ministers of Ukraine of December 10, 2003, Number 1891 on methodology of "Property valuation approval" [Постанова Кабінету Міністрів Украӥни від 10 грудня 2003 року № 1891 «Методика оцінки майна»].

\section{Porównanie wartości nieruchomości określonej na rynku polskim i ukraińskim w aspekcie historycznych zmian granic państw}

Streszczenie: $W$ związku ze zmianami granic państwowych, jakie miały miejsce w wyniku działań wojennych prowadzonych w Europie w pierwszej połowie XX wieku, część przemieszczającej się ludności pozostawiła swoje nieruchomości na terenie innych państw.

Państwo polskie rekompensuje swym obywatelom straty związane z nieruchomościami pozostawionymi poza obecnymi granicami Polski. W polskim prawie powstały procedury umożliwiające wycenę tego typu nieruchomości. Oparte są one na ustawie o gospodarce nieruchomościami. Wycena wykonywana jest na podstawie nieruchomości podobnych, położonych na obszarze rynków porównywalnych w aktualnych granicach Polski.

Celem pracy była weryfikacja, czy tak wyznaczona wartość odpowiada aktualnej wartości rynkowej na lokalnym rynku nieruchomości. Jako przykład posłużyła nieruchomość położona we Lwowie. Wartość nieruchomości szacowano dwukrotnie - na podstawie danych z rynku lokalnego (lwowskiego) oraz z rynku uznanego zgodnie z polskimi regulacjami prawnymi za porównywalny, tj. na podstawie danych o nieruchomościach z Krakowa.

\section{Słowa}

kluczowe: prawo do rekompensaty, wycena nieruchomości, rynki porównywalne 